\title{
BROECKINELLA HENSONI N. SP., A NEW LARGER BENTHIC FORAMINIFERA FROM THE UPPER MAASTRICHTIAN OF IRAN AND A REVISION OF THE GENUS BROECKINELLA HENSON, 1948
}

\author{
Felix Schlagintweit ${ }^{1 *} \&$ Koorosh Rashidi ${ }^{2}$
}

Received: 5 March 2020 / Accepted: 7 April 2020 / Published online: 14 April 2020

\begin{abstract}
A new larger benthic foraminifera is described as Broeckinella hensoni from the upper Maastrichtian Tarbur Formation of SW Iran (Zagros Zone). In comparison to the type species of the genus, Broeckinella arabica Henson, which also occurs in the Tarbur Formation, the new species has distinctly larger dimensions (e.g., size and thickness of test, chamber height). The first record of a microspheric specimen of $B$. arabica shows previously unrecorded annular chambers in the final test stage. Therefore, the generic diagnosis is herein emended. In the Tarbur Formation, both $B$. hensoni $\mathrm{n}$. sp. and B. arabica occur in foraminiferal-algal wackestones. However, B. arabica occurs in a wider range of microfacies, including packstones and grainstones. It is assumed that Broeckinella originated in the Upper Cretaceous with Broeckinella neumannae Gendrot. The upper Albian Broeckinella aragonensis Peybernès is herein transferred to the porcellaneous genus Peneroplis Montfort.
\end{abstract}

Keywords: Foraminiferida, taxonomy, biostratigraphy, Upper Cretaceous, Arabian Plate

\section{INTRODUCTION}

The larger agglutinating benthic foraminifera genus Broeckinella was established by Henson (1948) on the basis of an equatorial section (external view of a weathered surface, holotype specimen) from the Maastrichtian Simsima Formation of Dukhan No. 1 well of Qatar associated with Loftusia and Omphalocyclus. Nonetheless, there followed a long discussion about the type-strata belonging to the Paleocene and not the Maastrichtian (e.g., Drobne and Hottinger, 1971). The common occurrence of Broeckinella in the Maastrichtian of the Tarbur Formation of the Iranian Zagros (an equivalent to the Simsima Fm. of Qatar) acords with the original view of Henson (1948) (Schlagintweit and Rashidi, 2016). Henson placed Broeckinella (with subepidermal network, flabelliform to reniform chambers and, as now known, agglutinated wall) and Broeckina Munier-Chalmas [without subepidermal network, with shallow lateral partitions, annular chambers and porcellaneous wall structure, e.g., Caus et al., 2013] in the same family, the Meandropsinidae. It must be speculated that this misinterpretation of wall structure was due to the lack of thin-section specimens. According to the critical literature review of Cherchi and Schroeder (1978), Broeckinella has an initial planispiral stage and a flabelliform test morphology (not becoming annular in the adult part). This statement refers to the single specimen illustrated by Henson, that belongs to the macrospheric generation as clearly demonstrated by Cherchi and Schroeder (1991). Information on the microspheric generation has been lacking. These authors conclude that there is no verified other record of $B$. arabica besides that of its type-locality. The forms described as B. arabica by Drobne and Hottinger (1971) from the Thanetian of Slovenia were doubted as belonging to Henson's taxon. In this respect, Cherchi and Schroeder (1975) noted the lack of information about the initial part and missing evidence for the chamber morphology (flabelli- form or annular). Later, these Thanetian forms were ascribed to a new genus by Sirel and Gündüz (1985): Vania with the type-species being Vania anatolica. Vania differs from Broeckinella by its annular chambers in the final part of its adult test. More recently, another allied taxon was established by Sirel (2012) as Postbroeckinella (type-species Postbroeckinella flabelliformis), also from the Thanetian of Turkey characterized by an initial biserial stage (?) and a flabelliform test. In fact, the Late Cretaceous Broeckinella arabica and the two Thanetian taxa Vania and Postbroeckinella can only be reliably distinguished in sections passing through the initial stage and/or sections of adult specimens displaying either annular or flabelliform chambers (e.g., centered equatorial sections). Bearing in mind that in large-discoidal forms most sections are oblique ones, this makes a correct determination almost impossible when other accompanying taxa are missing, allowing an attribution either to the Late Cretaceous or Thanetian. It is worth noting that forms similar to Broeckinella are unknown from DanianSelandian strata. Last but not least, it should be mentioned that for these taxa the morphological variability and differences between micro- and megalospheric specimens are poorly known.

Concerning Broeckinella, there are three species (besides the type-species $B$. arabica) that have been described: Broeckinella neumannae (Santonian of France, Gendrot, 1968), Broeckinella magna (Valanginian of Switzerland, Septfontaine, 1978), and Broeckinella aragonensis (Late Albian of Spain, Peybernès, 1984). Broeckinella magna displays a coarsely agglutinated alveolar wall structure (e.g. holotype specimen in Septfontaine, 1978, pl. 1, fig. 1) but not a delicate subepidermal network as reported from B. arabica. Cherchi and Schroeder (1982a) note the resemblance of "B." magna to both Pseudochoffatella Deloffre and Balkhania Momontova and raise doubts about the exact geometric pattern of the foramina (? aligned in a row or cribrose). Broeckinella aragonensis

\footnotetext{
${ }^{1}$ Lerchenauerstr. 167, 80935 München, Germany, *Corresponding author: felix.schlagintweit@gmx.de

${ }^{2}$ Department of Geology, Yazd University, 89195-741 Yazd, Iran, kooroshrashidi@yazd.ac.ir
} 


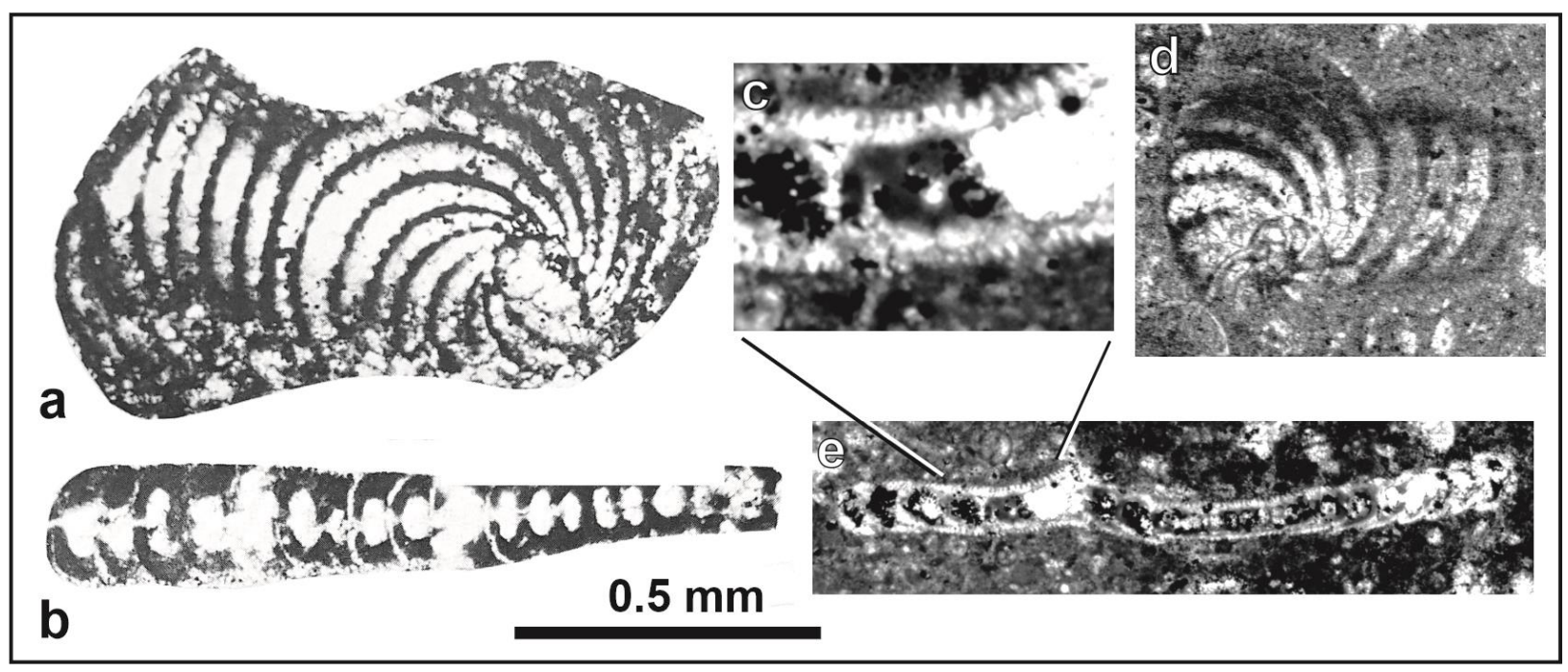

Fig. 1 Peneroplis aragonensis (Peybernès) nov. comb. a Equatorial section. b Broken axial section (both from Peybernès, 1984, pl. 1, fig. 1 and 7, Late Albian of Spanish Pyrenees). c Detail from d showing fine surface ornamentation (striae). d Slightly oblique equatorial section. e Subaxial section showing fine striae of surface ornamentation (c-e from the Late Albian Barcenaciones Formation, Cantabria, N-Spain, leg M. Najarro).

displays a homogeneous dark wall lacking a subepidermal network (text-fig. 1a-b). Among the three new taxa described by Peybernès (1984) from the upper Albian of Spain, Fischerina? carinata displays the same porcellaneous wall structure as "B." aragonensis, with a thin but distinct bright outer layer. Cherchi and Schroeder (1982b, pl. 2, figs. 1-7) illustrated the same form from the upper Albian of Asturia, northwestern Spain as "Soritidae inc. sed." Supplemented by our own material from the upper Albian of Cantabria (Najarro, 2015, for details) (Fig. 1ce), Broeckinella aragonensis is considered as a representative of Peneroplis De Montfort in accordance with the assumed porcellaneous wall texture, its peneroplid test morphology, multiple foramina, and test surface ornamentation (striae) (e.g., Peybernès 1984, pl. 3, fig. 17; see also text-Figure 1a-b). Peneroplis aragonensis can be compared with the late Albian-middle Cenomanian $P$. parvus De Castro, 1965 and the early late Cenomanian $P$. cairoensis Chiocchini, 2008. With a maximum test diameter of $4.5 \mathrm{~mm}$ (Peybernès, 1984), P. aragonensis is much larger then $P$. parvus (De Castro, 1965: up to 0.82 $\mathrm{mm}$ ) and also $P$. cairoensis (up to $1.2 \mathrm{~mm}$ ). In addition, the chambers of the latter are less arched than in $P$. aragonensis. It is worth mentioning that another porcellaneous soritid was described by Deloffre and Hamaoui (1969) as Pseudobroeckinella soumoulouensis from the Santonian of France.

In summary, with Pre-late Cretaceous of the genus doubtful, Broeckinella is herein considered as a foraminiferal genus originating in the Late Cretaceous Global Maturation Cycle of Hottinger (1999), with three species: $B$. neumannae Gendrot, $B$. arabica Henson, and $B$. hensoni n. sp. the later species as described herein the present paper from the Tarbur Formation of Iran.

\section{GEOLOGICAL OVERVIEW}

The Maastrichtian Tarbur Formation represents a shallow-water carbonate succession in SW Iran (Zagros Zone), rich in larger benthic foraminifera and calcareous 58 algae (James and Wynd, 1965). Towards the southwest, the Tarbur Formation interfingers with the Gurpi Formation that usually underlies the former. In the stratigraphic chart of Iran provided in 1995 by the Geological Society of Iran, the Tarbur Formation is assigned to the Campanian-Maastrichtian interval. In recent times several new genera of larger benthic foraminifera were described from the upper Maastrichtian of the Tarbur Formation (e.g., Schlagintweit and Rashidi, 2016, 2018; Consorti and Rashidi, 2018; Consorti et al., 2019). Herein Broeckinella hensoni n. sp. and Broeckinella arabica Henson are described from two localities: the Naghan and Mandegan sections (Fig. 2).

\section{STUDIED SECTIONS}

\section{Naghan section}

The studied section in the folded Zagros belt is located approximately $50 \mathrm{~km}$ south west of the town of Naghan, near the village Gandomkar and is herein named the Naghan section. The section occurs on the road from the towns of Naghan and Izeh. At this locality, the Tarbur Formation is underlain by the Gurpi Formation and overlain by the Paleocene Sachun Formation. Lithologically, the Gurpi Formation consists of dark, grey calacareous shale with planktonic foraminifera. The Sachun Formation consists of gypsum, red shales, anhydrite and some layers of carbonates. The thickness of the Tarbur Formation in the Naghan section is about $\sim 274 \mathrm{~m}$. It is composed of medium to thick-bedded grey limestone, shales and marls and can be subdivided into 5 units (from base to top)

- unit 1 (99 m), red to yellow shales

- unit 2 (61 m), medium- to thick-bedded grey limestones with Loftusia and rudist debris (calcarenites to calcirudites)

- unit 3 (33 m), intercalation of grey shales and cream to grey, medium- to thick-bedded limestones (calcilutites and calcarenite) 


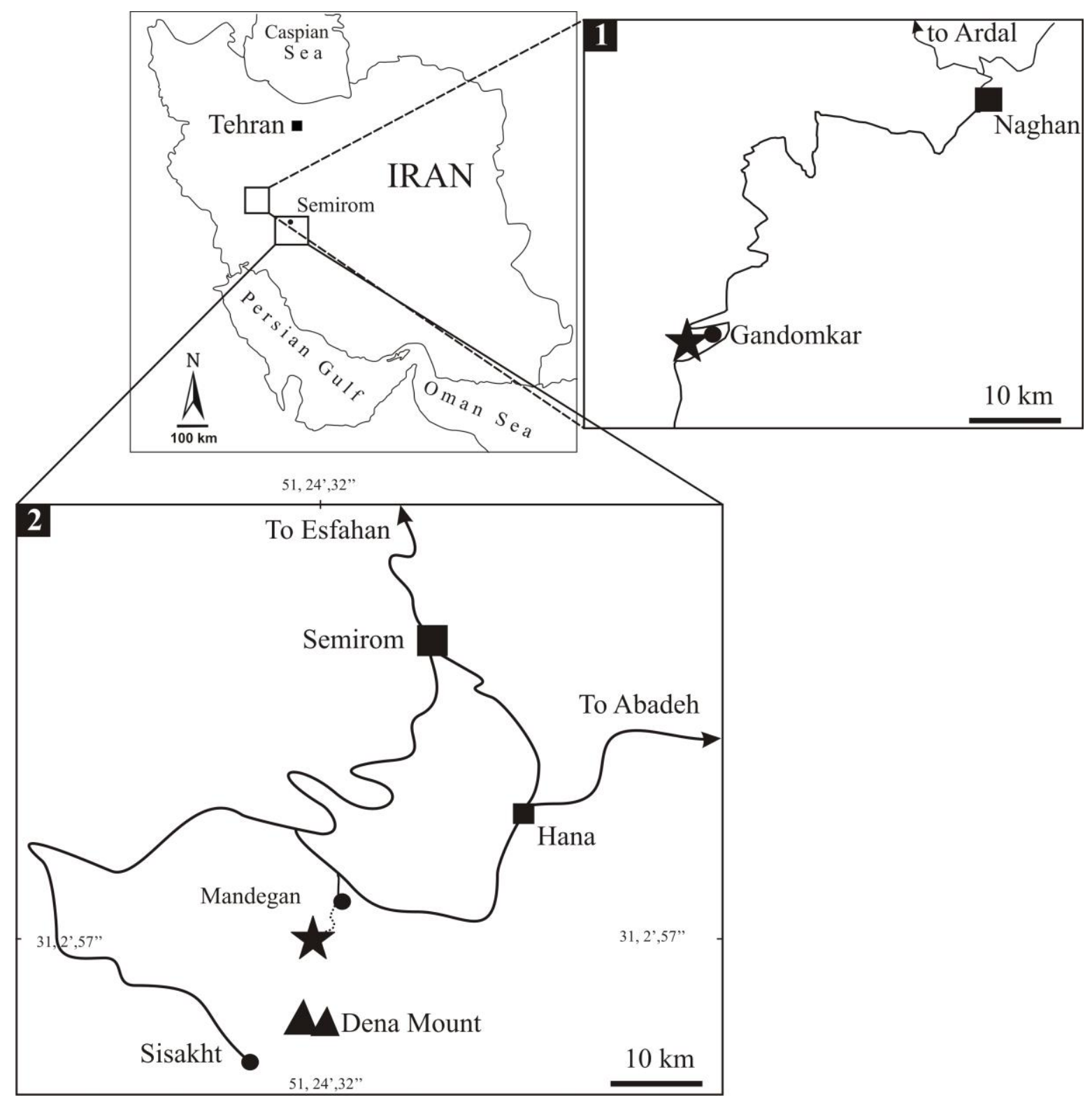

Fig. 2 Location of the Naghan and Mandegan sections in the Zagros Zone, SW Iran.

- unit 4 (38 m), thick-bedded to massive, grey to creamcoloured limestones containing broken rudist shells and tests of Loftusia (calcarenite, calcilutite, calcirudite) - unit 5 ( $41.6 \mathrm{~m})$, shales interbedded with medium- to thick-bedded yellow limestones containing Loftusia fragments.

Broeckinella hensoni n. sp. is irregularly distributed throughout the whole Tarbur Formation within the Naghan section from base to top. The type-level with the holotype specimen is from the middle/upper part of unit 4 (Fig. 3). The occurrence of Canalispina iapygia RoblesSalcedo et al. in unit 3 (see Septfontaine et al., 2019, fig. 2) evidences an upper Maastrichtian age (Robles-Salcedo et al., 2019). The coordinates of the base of the section are $\mathrm{N} 31^{\circ} 47^{\prime} 52^{\prime \prime}$ and $\mathrm{E} 50^{\circ} 32^{\prime} 53$ ".

\section{Mandegan section}

The study area, located in the High Zagros Belt, is situated north of Mount Dena, about $65 \mathrm{~km}$ south of the town of Semirom. The section of the Tarbur Formation is exposed about $10 \mathrm{~km}$ south of the village of Mandegan. Here the Tarbur Formation with a thickness of $\sim 272 \mathrm{~m}$ overlies conformably the Gurpi Formation. The top of the section is unconformably overlain by conglomerates of the Pliocene Bakhtiari Formation (see Bahrami, 2009, for details). Based on the lithostratigraphy, the section has been divided into three units (from base to top): unit 1 is dominated by thick-bedded limestones, unit 2 mostly contains medium-bedded limestones with intercalated marly limestone layers, and unit 3 consists of marly limestones. The occurrence of Siderolites calcitrapoides Lamarck and Canalispina iapygia Robles-Salcedo et al. in the lower part of the section evidence an upper Maastrichtian age (Robles-Salcedo et al., 2019). The coordinates of the base of the section are $31^{\circ} 2^{\prime} 58.13^{\prime \prime} \mathrm{N}$ and $51^{\circ} 24^{\prime} 34.58 " \mathrm{E}$.

\section{MATERIAL AND METHODS}

The seven thin-sections with the new species Broeckinella hensoni n. sp. illustrated herein from the Naghan 


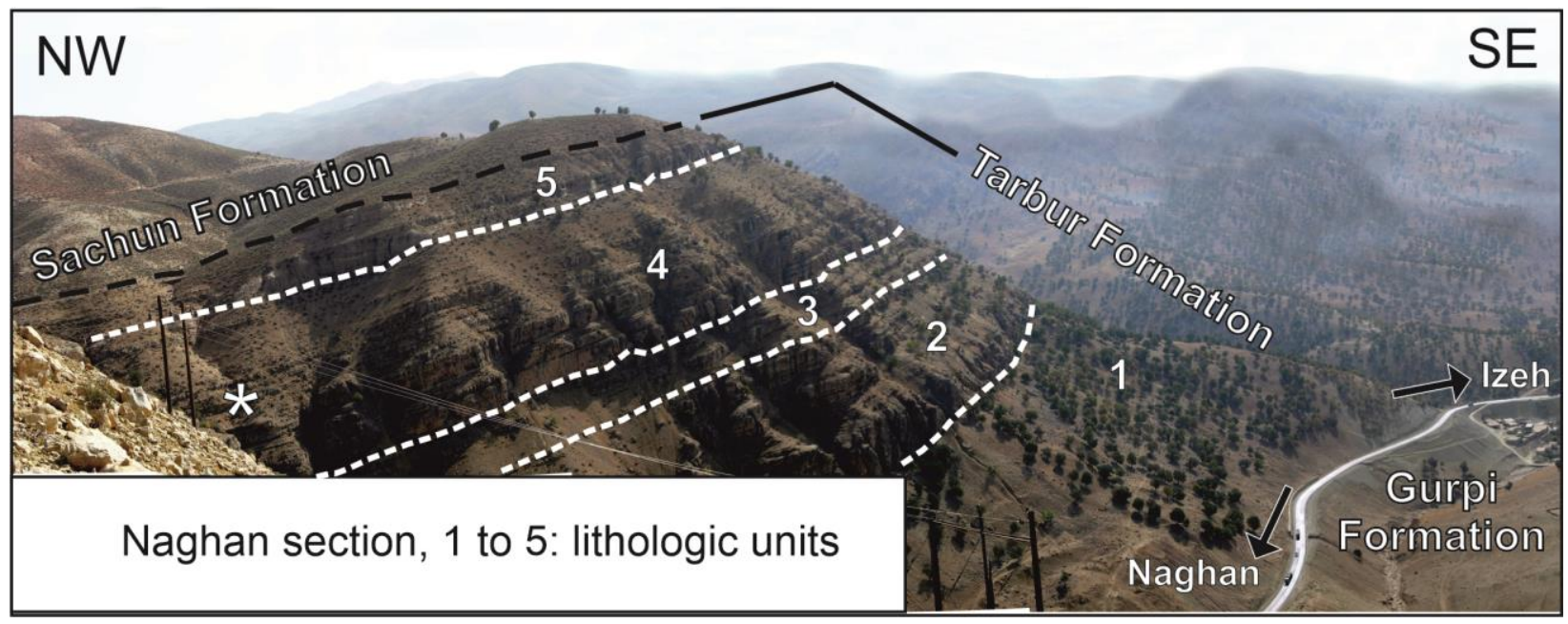

Fig. 3 Naghan section, along the road from Naghan to Izeh with the type-level of Broeckinella hensoni n. sp. marked by an asterisk (left side).

section (including the holotype) are deposited at the Geosciences Museum of Mashhad (in the Geological Survey of North-Iran East territory). In Table 1 the original sample numbers as designated in the field-campaigns and the corresponding official depository numbers are indicated. The two thin-section Rt 67-1 and Rt 72 (original sample numbers) from the Mandegan section are stored at the Bayerische Staatssammlung für Paläontologie und historische Geology, Munich, under the official number SNSBBSPG $2016 \mathrm{~V} 1$ to V 20. They are part of 20 thinsections from the Tarbur Formation stored in the framework of the orbitolinid study of the authors (Schlagintweit et al., 2016).

Table 1 Numbers of thin-sections (original field numbers) and official depository numbers of the Geosciences Museum of Mashhad (in the Geological Survey of NorthIran East territory).

\begin{tabular}{|l|l|l|}
\hline Number & $\begin{array}{l}\text { Orignal sample } \\
\text { number }\end{array}$ & $\begin{array}{l}\text { Depository-inventory } \\
\text { number }\end{array}$ \\
\hline 1 & 2NGN & Gmm13980F32 \\
\hline 2 & 2NG 38 & Gmm13980F33 \\
\hline 3 & 2NG 118 & Gmm13980F34 \\
\hline 4 & 2NG 153 & Gmm13980F35 \\
\hline 5 & 2NG 166 & Gmm13980F36 \\
\hline 6 & 2NG 172 & Gmm13980F37 \\
\hline 7 & NG 197-1 & Gmm13980F38 \\
\hline
\end{tabular}

\section{SYSTEMATIC PALEONTOLOGY}

The higher level classification follows Pawlowski et al. (2013). For other aspects of foraminiferal classification see Kaminski (2014) with modification by Albrich et al. (2015).

Phylum Foraminifera Orbigny, 1826

Class Globothalamea Pawlowski et al., 2013

Order Loftusiida Kaminski \& Mikhalevich, 2004

Suborder Loftusiina Kaminski \& Mikhalevich, 2004

Superfamily Loftusioidea Brady, 1884
Family Spirocyclinidae (Munier-Chalmas, 1887) Maync, 1950

Remarks: In the definition of the families Cyclamminidae and Spirocyclinidae, Albrich et al. (2015, p. 255) do not follow the classification of Kaminski (2014). According to these authors "the genera with polygonal subepidermal patterns should be ascribed to the Family Spirocyclinidae instead of the Cyclamminidae". In this definition, the genus Broeckinella possessing a polygonal subepidermal pattern should therefore be included in the Spirocyclinidae.

Subfamily Pseudochoffatellinae Loeblich \& Tappan, 1985

Genus Broeckinella Henson, 1948 emended

Remarks: The generic diagnosis of Loeblich and Tappan (1987, p. 104) only referred to the megalospheric form. It needs to be emended with respect to data obtained from a microspheric specimen described here. The diagnosis of Loeblich and Tappan (op. cit.) is emended as follows (added changes in bold letters)......."chambers rapidly increasing in breadth to become arcuate but not completely cyclical, so that the test is successively flabelliform, complanate, and finally reniform in the macrospheric stage. Microspheric stage with a few annular chambers, so that the test is ovoid to discoidal".

Broeckinella arabica Henson, 1948

Figs. 4b-d, 5-6.

*1948 Broeckinella arabica n. gen., n. sp. - Henson, p. 93, pl. 7, fig. 6, text-fig. 13a-c.

1978 Broeckinella arabica Henson - Cherchi and Schroeder, p. 514, fig. 1 A-C.

2004 Dicyclina schlumbergeri - Khosrow Tehrani and Afghah, pl. 2, fig. 4.

2008 Dicyclina schlumbergeri - Khosrow Tehrani et al., pl. 1 , fig. 6.

2016 Broeckinella arabica Henson - Schlagintweit and Rashidi, p. 57, fig. 9a-e.

Emended description: Test finely agglutinated, compressed, with numerous chambers rapidly increasing in width so that the megalospheric test becomes flabelliform. A tiny proloculus (diameter $\sim 0.07-0.1 \mathrm{~mm}$ ) is followed by about 8-10 planispiral chambers that increase 


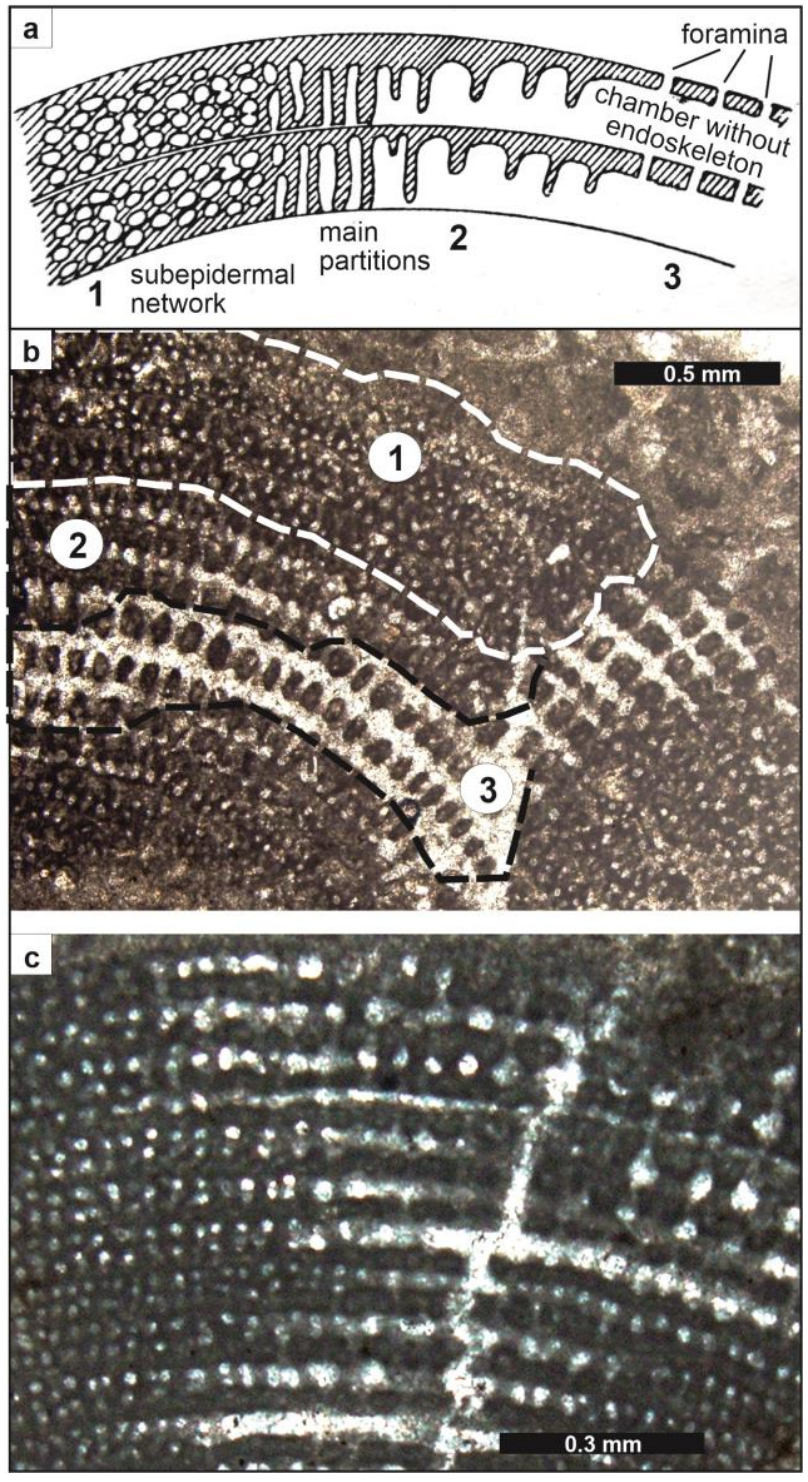

Fig. 4 Internal structure of Broeckinella arabica Henson. a Drawing of a slightly oblique equatorial section (slightly modified from Henson, 1947, fig. 13c; see also Cherchi and Schroeder 1978, fig. 1C). 1 = subepidermal layer (network; exoskeleton), 2 = zone with transverse partitions only, $3=$ undivided chamber interior (lacking endoskeleton); septa with foramina. b Tangential equatorial section of Broeckinella arabica showing the three zones of Henson (1948). Thin-section Rt 85, Mandegan section. c Tangential equatorial section showing main partitions aligned between successive chambers (detail from Fig. 6d). Thin-section NG 42-1, Naghan section. rather rapidly in width (Fig. 6e). The chamber margins are subdivided by exoskeletal elements, both vertical and horizontal resulting in a meshwork (or pattern) of tiny polygonal cells displayed in shallow tangential sections (= zone 1 in Henson 1948; see Fig. 4a) (Figs. 4b, 6a-d). Toward the chamber interior a zone follows where only main partitions are present, aligned between successive chambers (= zone 2 in Henson 1948; see Fig. 4a) (Figs. $4 c, 6 b, d)$. The central part is undivided (Figs. 4b, 6c, e). The multiple foramina are arranged in the median plane, not related to the main partitions (that can therefore not be termed septula). The microspheric test is ovoid to discoidal due to final annular chambers (Fig. 5b-c). A proloculus is not observable. The planispiral part, contrasting the A-form, consists of numerous ( 26) chambers. The internal structure is identical to the A-form.

Remarks: The material of $B$. arabica from the Tarbur Formation does not include centered sections. Data on the test dimensions therefore only comprise incomplete sections attaining a maximum size of $2.4 \mathrm{~mm}$ for megalospheric and up to $4.6 \mathrm{~mm}$ for microspheric forms (Tab. 2). $B$. arabica is intermediate in size between the distinctly smaller B. neumannae and the larger B. hensoni n. sp. (Tab. 3). The description of Henson (1948) was based on a single specimen, a megalospheric form (see Cherchi and Schroeder, 1978). The specimen from the Tarbur Formation illustrated in Fig. $5 b$ is the first record of a microspheric specimen. The differences between the two generations are summarized in Table 2.

B. arabica was figured as Dicyclina schlumbergeri from the Maastrichtian of the Tarbur Formation by Khosrow Tehrani and Afghah (2004) and the Maastrichtian of the Amiran Formation (SW Iran, Zagros Zone) where the authors distinguished a Loftusia-Dicyclina assemblage zone. Dicyclina schlumbergeri is rather common in the Tarbur Formation (see Schlagintweit and Rashidi, 2018). Broeckinella hensoni Schlagintweit and Rashidi nov. sp. Figs. 5a, 7-8.

Holotype: Equatorial section of an assumed macrospheric specimen showing flabelliform test and illustrated in Fig. 7f, thin-section $2 \mathrm{NG}$ N. The diameter of the holotype specimen is $\sim 3.65 \mathrm{~mm}$.

Table 2 Megalospheric versus microspheric generations of Broeckinella arabica Henson (A-form: data from Cherchi and Schroeder, 1978; B-form: this work, specimen shown in figure 5b-d).

\begin{tabular}{|l|c|c|}
\hline generation & megalospheric (A) form & microspheric (B) form \\
\hline number chambers planispiral part & $\sim 10$ & $\sim 26$ \\
\hline diameter proloculus & $0.07-0.1 \mathrm{~mm}$ & not discernible \\
\hline test diameter & $3.1 \mathrm{~mm}$ (holotype) & $\sim 4.6 \mathrm{~mm}$ \\
& & $(\sim 4.2$ preserved part) \\
\hline adult final chambers & flabelliform & annular \\
\hline test morphology & fan-shaped & ovoidal to discoidal \\
\hline
\end{tabular}


Table 3 Summary table of the biometric parameters of Broeckinella species. Data from Henson (1948), Gendrot (1968), Cherchi and Schroeder (1978), and this work. * measured from the original papers.

\begin{tabular}{|l|c|c|c|}
\hline \multicolumn{1}{|c|}{ species } & B. arabica & B. neumannae & B. grandis n. sp. \\
\hline Type-locality & $\begin{array}{c}\text { Maastrichtian of Qatar } \\
\text { (Henson, 1948) }\end{array}$ & $\begin{array}{c}\text { Santonian of France } \\
\text { Gendrot (1968) }\end{array}$ & Maastrichtian of Iran \\
\hline Test diameter (mm) & $\begin{array}{c}\text { up to 3.1 (A-form) } \\
\text { up to 4.6 (B-form) }\end{array}$ & $\begin{array}{c}\text { up to 1.5 mm } \\
\text { (A-form) }\end{array}$ & up to 7.5 (?B-form) \\
\hline Test thickness (mm) & $\sim 0.3$ & up to 0.22 & up to 0.4 \\
\hline Number chambers last mm & $8-14 *$ & $6-8 *$ & $5-7$ \\
\hline Diameter foramina $(\mathrm{mm})$ & $0.02-0.04$ & 0.06 & $0.05-0.07$ \\
\hline Proloculus diameter $(\mathrm{mm})$ & $\sim 0.1$ & $0.07-0.09 *$ & - \\
\hline
\end{tabular}

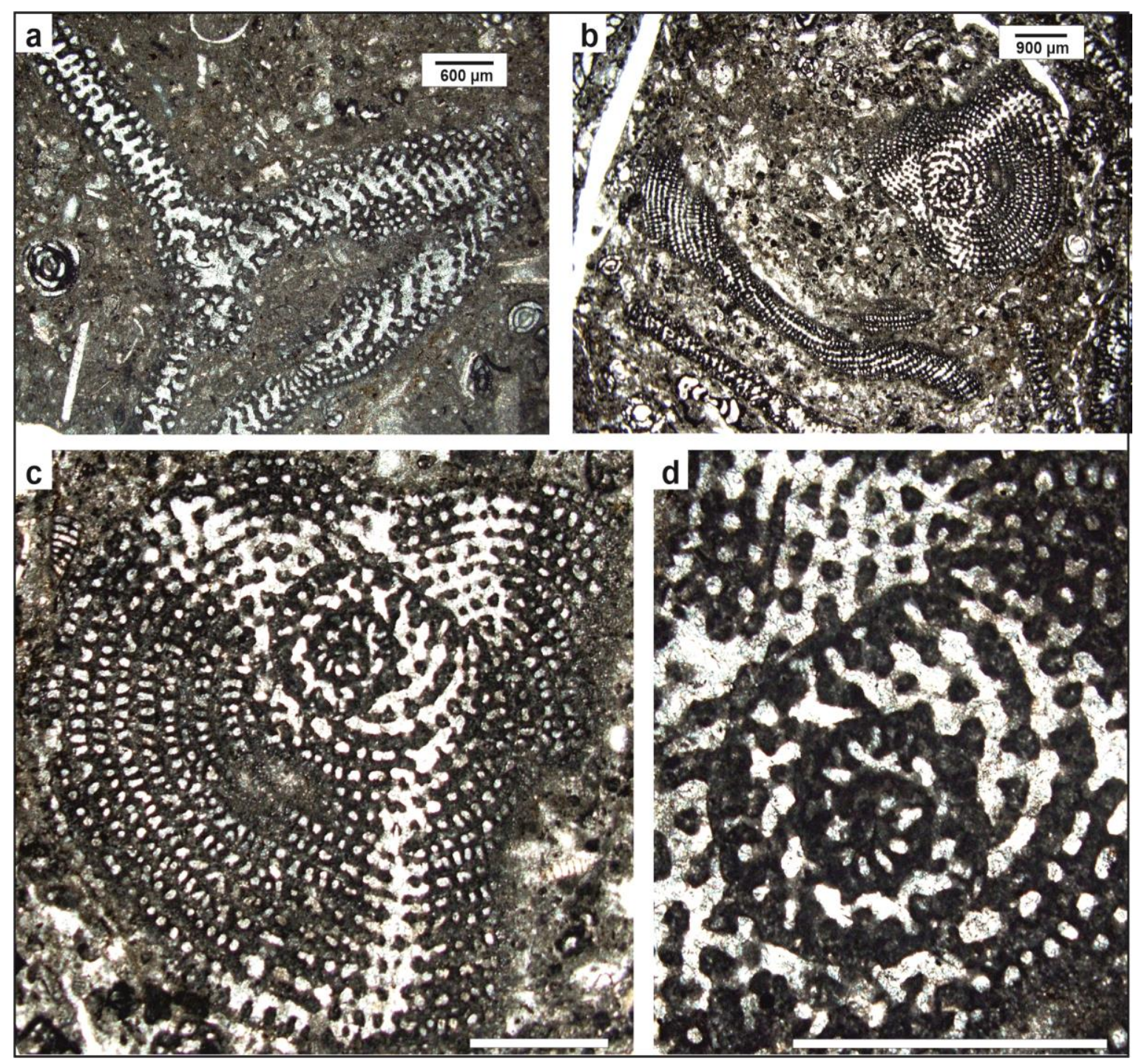

Fig. 5 Broeckinella hensoni n. sp. (a) and Broeckinella arabica Henson (b-d) from the upper Maastrichtian of the Tarbur Formation, Naghan section. a Foraminiferal wackestone with Broeckinella hensoni n. sp., thin-section 2NG 197. b Foraminiferal wackestone with Broeckinella arabica Henson, 2NG 128-1. c-d Details from b, showing a microspheric specimen. Scale bars in $\mathbf{c}$ and $\mathbf{d}=1 \mathrm{~mm}$. 
Etymology: The species name is dedicated to Francis Roger Spencer Henson (1901-1967) in honour for his fundamental works on larger imperforate foraminifera from the Middle East area. For further information on F.R.S. Henson and his merits see Hughes (2013).

Type-locality: Naghan section (Figs. 2-3).

Type-level: Late Maastrichtian of the Tarbur Formation. Description: Test finely, agglutinating, large (up to almost $8 \mathrm{~mm}$ ), flattened with an early evolute planispiral stage followed by a flabelli- to reniform adult growth stage (Fig. 7f). Axial sections display almost constant chamber width (Fig. 7a). Further details on the early stage are limited by the available sections. The adult part consists of up to 50 chambers. There are five to seven chambers in the last $\mathrm{mm}$ of the test. Wall finely agglutinated. Exoskeleton consisting of one short horizontal and two orders (short, and longer) of subepidermal vertical (or radial) partitions (beams and rafters) together forming a subepidermal network (Fig. 8e). Due to the shortness of the secondary partitions this network of polygonal cells is only visible in shallow tangential sections. Longer vertical partitions (beams) are aligned between successive chambers, and reach slightly deeper into the chamber lumen. The central part of the chamber lumen is undivided (e.g., Fig. 8e in the lower part; see Henson, 1948: fig.13c). Multiple foramina (one row) arranged in the median plane. Microspheric specimens not reported.

Dimensions: See table 3.

Comparisons: Amongst the three Late Cretaceous species of the genus, Broeckinella hensoni is distinctly larger then B. arabica Henson (double the size!) and B. neumannae Gendrot (five times larger!) (see table 3 ). With respect to the time-equivalent $B$. arabica, the distinctively lower number of chambers per last $\mathrm{mm}$ test length (8 to 14 in $B$. arabica against 5 to 7 in $B$. hensoni), due to a greater chamber height, is notable.

\section{ACKNOWLEDGMENTS}

Thanks to Idoia Rosales and Maria Najarro (Madrid) for providing the thin-sections with "Broeckinella" aragonensis. Helpful comments of the two reviewers Lorenzo Consorti (Trieste) and Michael Kaminski (Dharan) are kindly acknowledged. Mike Simmons (London) assisted in revising the English language in the final version.

\section{REFERENCES}

Albrich, S., Boix, C., Caus, E., 2015. Selected agglutinated larger foraminifera from the Font de les Bagasses unit (Lower Campanian, southern Pyrenees). Carnets de Géologie 15 (18): 245-267.

Caus, E., Parente, M., Vicedo, V., Frijia, G., Martínez, R., 2003. Broeckina gassoensis sp. nov., a larger foraminiferal index fossil for the middle Coniacian shallow-water deposits of the Pyrenean Basin (NE Spain). Cretaceous Research, 45: 76-90.

Cherchi, A., Schroeder, R., 1978. Revision of the type of Broeckinella arabica Henson (Foram.) from Qatar Peninsula (Arabia). Neues Jahrbuch für Geologie und Paläontologie Monatshefte, 9: 513-520.
Cherchi, A., Schroeder, R., 1982a. Sobre la Edad de la Transgresion Mesocretacica en Asturias. Cuadernos Geología Ibérica, 8: 219-233.

Cherchi, A., Schroeder, R., 1982b. Précisions sur Pseudochoffatella Deloffre et remarques sur Balkhania balkhanica Mamontova (Foraminifères). Revue de Micropaléontologie, 25: 154-162.

Chiocchini, M., 2008. New benthic foraminifers (Miliolacea and Soritacea) from the Cenomanian and Upper Turonian of the Monte Cairo (Southern Latium, Central Italy). Memoire descrittive della Carta Geologica d' Italia, 84: 171-202.

Consorti, L., Rashidi, K., 2018. A new evidence of passing the Maastichtian-Paleocene boundary by larger benthic foraminifers: The case of Elazigina from the Maastrichtian Tarbur Formation of Iran. Acta Palaeontologica Polonica, 63 (3): 595-605.

Consorti, L., Schlagintweit, F., Rashidi, K., 2019. A new Idalina (Milioloidea, benthic Foraminifera) and some associated fauna from the upper Maastrichtian Tarbur Formation of SW Iran. Historical Biology. https://doi.org/10.1080/08912963.2019.1663842.

De Castro, P., 1965. Su alcune Soritidae (Foraminiferida) del Cretacico della Campania. Note biostratigrafique sul gruppo montuoso del Tifata. Bolletino della Società dei Naturalisti in Napoli, 74: 317-372.

Deloffre, R., Hamaoui, M., 1969. Biostratigraphie des "Brèches de Soumoulou" et déscription de Pseudobroeckinella soumoulensis n. gen., n. sp., foraminifère du Crétacé supérieur d' Aqutitaine. Bulletin du Centre de Recherches Pau-SNPA, 3: 5-31.

Drobne, K., Hottinger, L., 1971. Broeckinella und Saudia (Foraminiferida) aus dem nordwestlichen Teil Jugoslawiens, ihre morphologische und stratigraphische Verbreitung. Razprave slovenska Akademija Znanosti Umetnosti, 14 (7): 215-238.

Gendrot, C., 1968. Stratigraphie et micropaléontologie du Sénonien de la région des Martigues près Marseille (Bouches-du-Rhône). Eclogae Geologicae Helvetiae, 61 (2): 657-694.

Henson, F.R.S., 1948. Larger imperforate Foraminifera of south-western Asia. Families Lituolidae, Orbitolinidae and Meandropsinidae. London, Monograph British Museum (Natural History), 127 pp.

Hughes, G.W., 2013. Micropalaeontologists of Saudi Arabia and other Gulf countries. In: Bowden, A.J., Gregory, F.J., Henderson, A.S. (eds): Landmarks in Foraminiferal Micropalaeontology: History and Development. The Micropaleontological Society, Spec. Pubs.: 145-157.

Hottinger, L., 2001. Learning from the past. In: LeviMontalcini, R. (ed.): Frontiers of Life, vol. 4, part 2: Discovery and spoliation of the biosphere, p. 449-477. Academic Press (London \& San Diego).

James, G.A., Wynd, J.G., 1965. Stratigraphic Nomenclature of Iranian Oil Consortium Agreement Area. AAPG Bulletin, 49: 2218-2232.

Kaminski, M.A., 2014. The year 2010 classification of the agglutinated Foraminifera. Micropaleontology, 60: 89-108.

Najarro, M., 2015. Las plataformas carbonatadas y sistemas deltaicos del Aptiense-Albiense inferior del noroeste de Cantabria: registro de cambios 


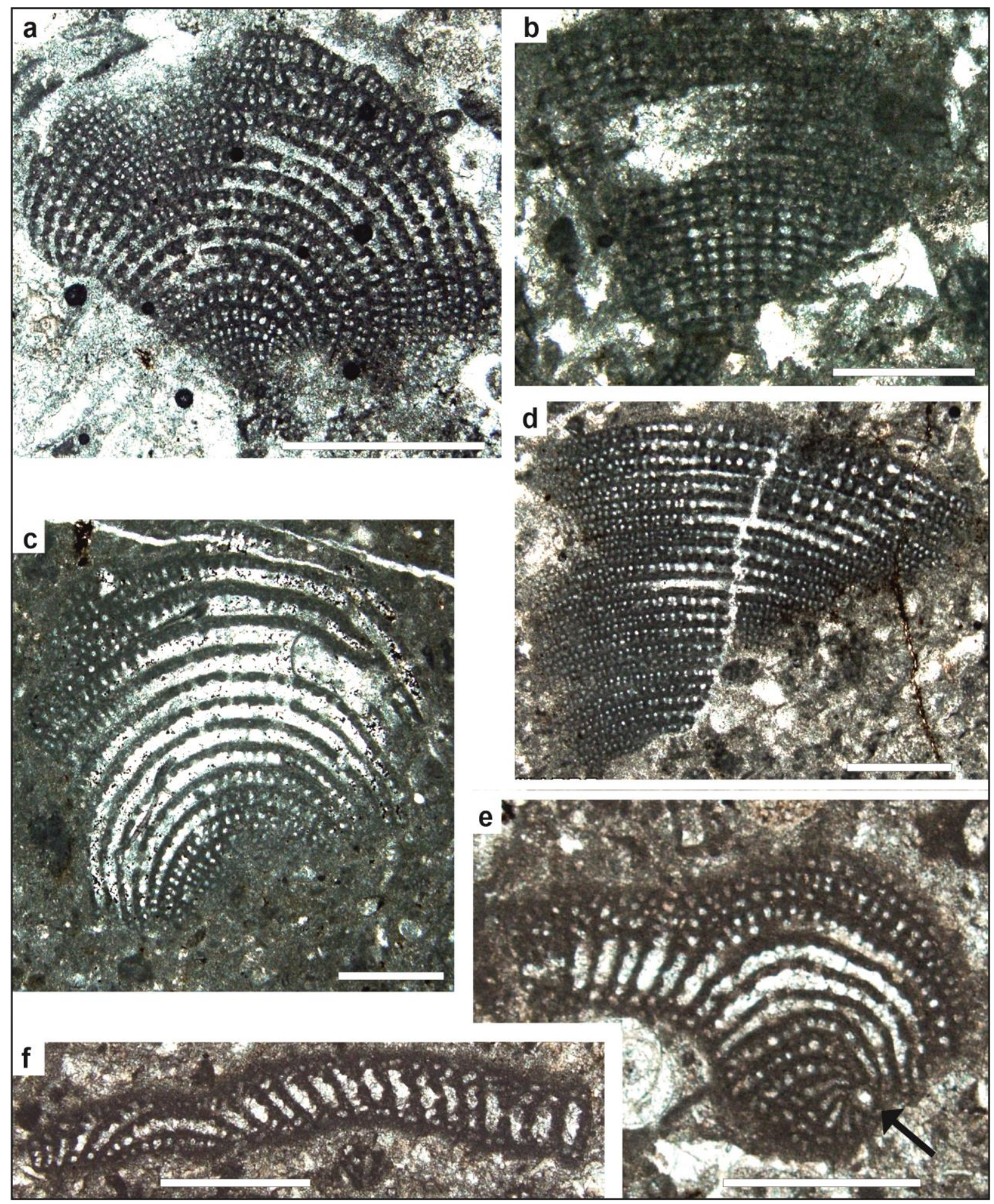

Fig. 6 Broeckinella arabica Henson, upper Maastrichtian Tarbur Formation of the Mandegan (a, d) and Naghan sections (bc, e-f), Zagros Zone, SW Iran. a, c-d Oblique equatorial sections, partly fragmentary, in some parts crossing the subepidermal network (e.g., $\mathbf{a}$ and left side of $\mathbf{d}$ ). Note the undivided central part of the chambers in $\mathbf{c}$. $\mathbf{b}$ Tangential section in the plane with only main partitions aligned between subsequent chambers (= zone 2 in Henson 1948; see Fig. 6a). e-f Oblique sections. Note initial planispiral part in the megalospheric specimen in e passing the proloculus (arrow). Note also the chambers undivided in the central part in e. Thin-sections: Rt 104 (a), NG 42-1 (b), NG 21 (c), Rt 85 (d), 2NG 49 (e), 2 NG 112 (f). Scale bars $0.5 \mathrm{~mm}$. 


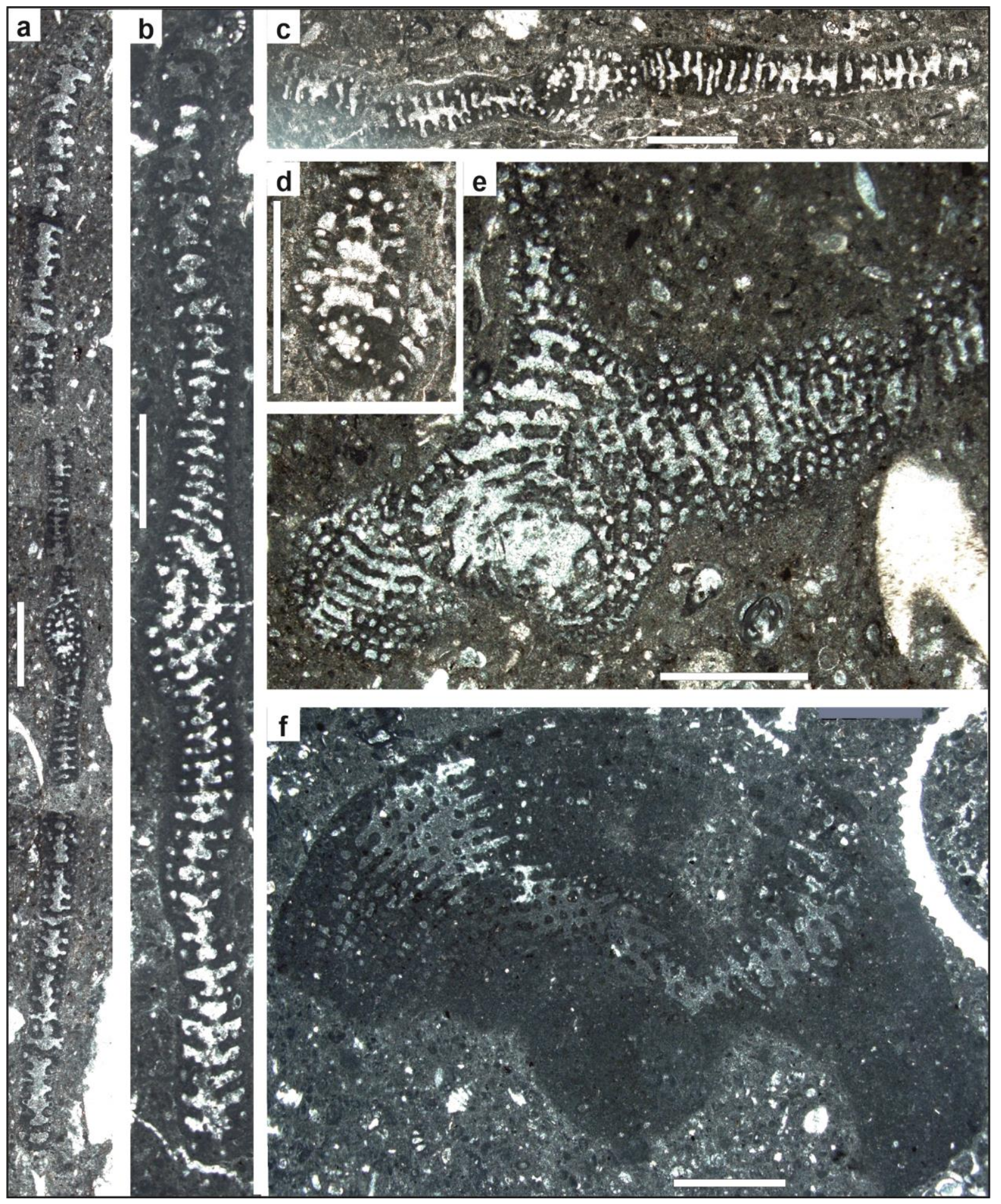

Fig. 7 Broeckinella hensoni n. sp., upper Maastrichtian Tarbur Formation of the Naghan section, Zagros Zone, SW Iran. a, c Subaxial sections. Specimen shown in A displays more than 40 chambers in the uncoiled adult part. d Detail from $\mathbf{c}$ showing initial coiled part. e Oblique equatorial section. f Slightly oblique equatorial section showing flabelliform test morphology (test diameter: $\sim 6.6 \mathrm{~mm}$ ). Thin-sections: 2NG 153 (a), 2NGN (b, f), 2NG 38 (c-d), NG 197-1 (e). Scale bars $1.0 \mathrm{~mm}$. 


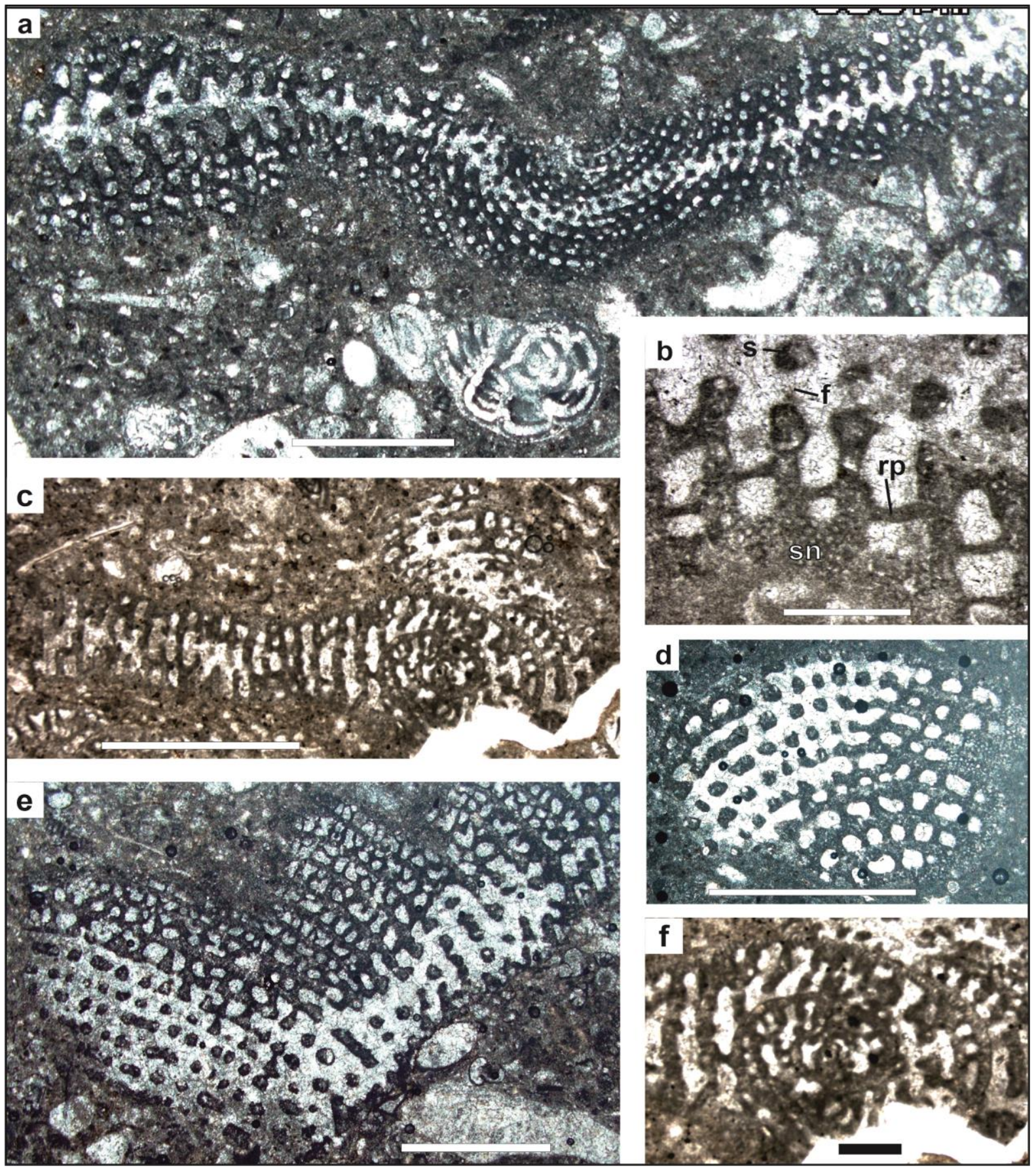

Fig. 8 Broeckinella hensoni n. sp., upper Maastrichtian Tarbur Formation of the Naghan (a, d-e) and Mandegan (b-c, f) sections, Zagros Zone, SW Iran. a Oblique equatorial section. Note porcelaneous test of Cuvillerinella sp. below. b Detail showing fine subepidermal network (sn, below), followed by zone with radial partitions (rp) only and finally the undivided central chamber part with foramina (f) piercing the septa (s). c Oblique section cutting the initial planispiral part. d-e Oblique equatorial sections showing zones of different internal structure (see Text-Figure 3 ). $\mathbf{f}$ Detail from $\mathbf{c}$ showing initial planispirally coiled part with numerous chambers. Note also the fine subepidermal network and main partitions (right side). Thin-sections: 2NG 166 (a), Rt 67-1 (b), RT 72 (c, f), 2NG 118 (d), 2NG 172 (e). Scale bars $1.0 \mathrm{~mm}$ for a, c-e, $0.2 \mathrm{~mm}$ for b and $\mathbf{f}$. 
paleoambientales y eventos anóxicos. PhD Thesis. Madrid, Universidad Complutense de Madrid, $450 \mathrm{pp}$.

Pawlowski, J., Holzmann, M., Tyszka, J., 2013. New supraordinal classification of Foraminifera: Molecules meet morphology. Marine Micropaleontology, 100: $1-10$.

Peybernès, B., 1984. Foraminifères benthiques nouveaux de l'Albien supérieur du Massif du Turbón (Pyrénées Espagnoles). Benthos '83; $2^{\text {nd }}$ International Symposium on Benthic Foraminifera (Pau, April 1983): 491499.

Robles-Salcedo, R., Vicedo, V., Parente, M., Caus, E., 2019. Canalispina iapygia gen. et sp. nov.: the last Siderolitidae (Foraminiferida) from the upper Maastrichtian of southern Italy. Cretaceous Research, 98: 84-94.

Schlagintweit, F., Rashidi, K., Babadipour, M., 2016. Orbitolinid foraminifera from the Late Maastrichtian of the Tarbur Formation (Zagros Zone, SW Iran). Acta Palaeontologica Romaniae, 12 (2): 29-46.

Schlagintweit, F., Rashidi, K., 2016. Some new and poorly known benthic foraminifera from late Maastrichtian shallow-water carbonates of the Zagros Zone, SW Iran. Acta Palaeontologica Romaniae, 12 (1): 53-70.
Schlagintweit, F., Rashidi, K., 2018. Suraqalatia brasieri Görmus, Lawa \& Nuaimy, 2017 (Larger benthic foraminifera; Suraqalatiidae n. fam.) from the Late Maastrichtian of the Tarbur Formation and remarks on Dicyclina Munier-Chalmas. Acta Palaeontologica Romaniae, 14 (1): 21-29.

Septfontaine, M., 1978. Broeckinella magna sp. nov., un nouveau grand foraminifère dans le Valanginien du Jura Méridional (Savoie, France). Revue de Micropaléontologie, 21 (1): 28-38.

Septfontaine, M., Schlagintweit, F., Rashidi, K., 2019. Pachycolumella nov. gen., shallow-water benthic imperforate foraminifera and its species from the Maastrichtian and Paleocene of Iran. Micropalaeontology, 65 (2): 145-160.

Sirel, E., 2012. Seven new larger benthic foraminiferal genera from the Paleocene of Turkey. Revue de Paléobiologie, 31 (2): 267-301.

Sirel, E., Gündüz, H., 1985. Vania, a new foraminiferal genus from the Thanetian of the Van region (East Turkey). MTA (Mineral Research and Exploration) Bulletin, 101/102: 20-24. 